\title{
Predicting Downward Longwave Radiation for Various Land Use in All-Sky Condition: Northeast Florida
}

\author{
Chi-Han Cheng ${ }^{1}$ and Fidelia Nnadi ${ }^{2}$ \\ ${ }^{1}$ Applied Hydrometeorological Research Institute, Nanjing University of Information Science \& Technology, No. 219, Ningliu Road, \\ Nanjing, Jiangsu 210044, China \\ ${ }^{2}$ Department of Civil, Environmental and Construction Engineering, University of Central Florida, Orlando, FL 32816, USA
}

Correspondence should be addressed to Chi-Han Cheng; herrymarry@gmail.com

Received 3 January 2014; Accepted 13 February 2014; Published 22 April 2014

Academic Editor: Julio Diaz

\begin{abstract}
Copyright (C) 2014 C.-H. Cheng and F. Nnadi. This is an open access article distributed under the Creative Commons Attribution License, which permits unrestricted use, distribution, and reproduction in any medium, provided the original work is properly cited.

Accurate estimate of the surface longwave radiation is important for the surface radiation budget, which in turn controls evaporation and sensible heat fluxes. Regional land use changes can impact local weather conditions; for example, heterogeneous land use patterns and temporal changes in atmospheric circulation patterns would affect air temperature and water vapor pressure, which are more commonly used as inputs in existing models for estimating downward longwave radiation ( $\mathrm{LW}_{\mathrm{d}}$ ). In this study, first, we analyzed the cloud cover and land use covers impacts on $\mathrm{LW}_{\mathrm{d}}$. Next, $\mathrm{LW}_{\mathrm{d}}$ on all-sky conditions were developed by using the existing land use-adapted model and cloud cover data from the region of Saint Johns River Water Management District (SJRWMD), FL. The results show that factors, such as, seasonal effects, cloud cover, and land use, are of importance in the estimation of $\mathrm{LW}_{\mathrm{d}}$ and they cannot be ignored when developing a model for $\mathrm{LW}_{\mathrm{d}}$ prediction. The all-sky land use-adapted model with all factors taken into account performs better than other existing models statistically. The results of the statistical analyses indicated that the BIAS, RMSE, MAE, and PMRE are $-0.18 \mathrm{Wm}^{-2}, 10.81 \mathrm{Wm}^{-2}, 8.00 \mathrm{Wm}^{-2}$, and $2.30 \% ;-2.61 \mathrm{Wm}^{-2}, 14.45 \mathrm{Wm}^{-2}, 10.64 \mathrm{Wm}^{-2}$, and $3.19 \% ;-0.07 \mathrm{Wm}^{-2}, 10.53 \mathrm{Wm}^{-2}, 8.03 \mathrm{Wm}^{-2}$, and $2.27 \%$; and $-0.62 \mathrm{Wm}^{-2}, 13.97 \mathrm{Wm}^{-2}, 9.76 \mathrm{Wm}^{-2}$, and $2.87 \%$ for urban, rangeland, agricultural, and wetland areas, respectively.
\end{abstract}

\section{Introduction}

Accurate estimate of downward longwave radiation $\left(\mathrm{LW}_{\mathrm{d}}\right)$ is necessary for calculating the net radiation, which in turn modulates the magnitude of the surface energy budgets, including latent heat [1]. This knowledge is also required for (a) forecasting of temperature variation, frost occurrence, and cloudiness, (b) estimation of climate variability and global warming, and (c) design of radiant cooling systems $[1,2]$.

The downward longwave radiation is a thermal infrared energy (in the wavelength of 4.0-100 $\mu \mathrm{m}$ ), mainly controlled by water vapor and aerosols such as cloud water droplets, $\mathrm{CO}_{2}$, and $\mathrm{O}_{3}$ molecules [3]. The longwave radiation is more difficult and expensive to measure than shortwave radiation because it is not a conventional measurement and thus its measurement is rarely included in meteorological stations [4]. Moreover, due to poor vertical resolution of water vapor data and difficulties associated with the atmospheric emissivity and temperature, many reasonably successful techniques have been developed in recent decades that estimate $\mathrm{LW}_{\mathrm{d}}$ based on the screen-level humidity and air temperature measurements. Angstrom [5] first observed an empirical relationship between downward longwave clear-sky irradiance and vapor pressure. Following his pioneering work, several parameterizations have been developed for $\mathrm{LW}_{\mathrm{d}}$ using synoptic observations [6-15].

The major drawback of previous studies is that their methods did not perform well in other locations, since they utilized local empirical coefficients. This is mainly caused by the significant variation of the coefficients in those models, due to the variability of air temperature and water vapor pressure, which in turn resulted from the spatial change in land use pattern and temporal change in atmospheric circulation. At land scale, human activities 
affect regional climate by changing the land use characteristics that impact the distributions of ecosystem, energy (latent and sensible heat), and mass fluxes (e.g., water vapor, trace gases, and particulates). These contrasting land use patterns induce convection and circulation that affect the cloud formation and precipitation. For example, when large areas of forest are cleared, reduced transpiration results in less cloud formation, less rainfall, and increased drying of the earth surface [16]. Previous studies on measurement of some radiation components (incoming shortwave radiation or net energy balance) focused on specific land use type, such as grass, short vegetation, bare soil, forest, and few crops, but disregarded urban areas and water-covered areas [17-19].

Therefore, a long-term monitoring and modeling of radiation components especially longwave radiation on various land use types including urban and wetland areas rather than agricultural and rangeland areas only are essential and critical. Rizou and Nnadi [15] developed a land use-adapted model which superpositioned nonlinear temperature effects and water vapor in one equation to account for the net impact on clear sky emissivity. Their model was robust and adaptable for different land use areas. The statistical parameters, including normalized mean bias errors (MBE) and root mean square errors (RMSE), are smaller than those of other existing models, which showed the model's good performance relative to others. In their study, three-month data in spring 2004 at current study area were analyzed but the seasonal variation and cloud effect were not considered on the various land use effects.

Culf and Gash [9] in considering a sinusoidal variation between wet and dry season showed that the leading coefficients of $\mathrm{LW}_{\mathrm{d}}$ regression model were different. This is similar to other meteorological variables, such as temperature, solar radiation, and water vapor pressure. In the dry season, the lapse rate of water vapor is lower than a standard atmosphere. On the other hand, the wet season is more humid and has a higher water vapor lapse rate. Other studies suggested that seasonal analysis and adjustment of $\mathrm{LW}_{\mathrm{d}}$ model are necessary and critical in long-term analysis $[1,4,12]$.

Rizou and Nnadi [15] indicated that the clouds would result in more noise in diurnal pattern of radiation, while Crawford and Duchon [1] argued that the utility of most techniques applicable to clear sky has great limitations. Previous studies also suggested that cloud cover plays an important role in preventing radiation deficit. These studies stated that thick clouds primarily reflect solar radiation and cool the surface of the earth, while high and thin clouds mainly transmit incoming solar radiation. However, it was also suggested that thick clouds trap some of the outgoing infrared radiation emitted by the earth and radiate it back downward, thereby warming the surface of earth. Therefore, several researchers have proposed locally adjusted equations for $\mathrm{LW}_{\mathrm{d}}$ fluxes in cloudy condition, such as Jacobs [8] for Baffin Island, Canada, Maykut and Church [7] for Alaska, United States, Sugita and Brutsaert [20] for Kansas, United States, Konzelmann et al., [21] for Greenland, and Crawford and Duchon [1] for Oklahoma, United States.
TABLE 1: Existing $L_{\mathrm{d}}$ model for all-sky condition.

\begin{tabular}{lcc}
\hline Parameterization & $\begin{array}{c}\text { Experimental } \\
\text { site }\end{array}$ & Equation \\
\hline Maykut and Church [7] & Alaska (USA) & (a) \\
$\mathrm{LW}_{\mathrm{d}}=\mathrm{LW}_{\mathrm{dc}} \times\left(1+0.22 \times C^{2.75}\right)$ & Baffin Island & (b) \\
Jacobs [8] & (Canada) & \\
$\mathrm{LW}_{\mathrm{d}}=\mathrm{LW}_{\mathrm{dc}} \times(1+0.26 \times C)$ & Kansas (USA) & (c) \\
Sugita and Brutsaert [20] & Southern & (d) \\
$\mathrm{LW}_{\mathrm{d}}=\mathrm{LW}_{\mathrm{dc}} \times\left(1+0.0496 \times C^{2.45}\right)$ & Brazil & \\
Duarte et al. $[12]_{\mathrm{LW}_{\mathrm{d}}=\mathrm{LW}_{\mathrm{dc}} \times\left(1+0.242 \times C^{0.583}\right)}$ & & \\
\hline
\end{tabular}

TABLE 2: ASOS cloud amount report.

\begin{tabular}{lccc}
\hline $\begin{array}{l}\text { ASOS measured } \\
\text { amount in \% of sky }\end{array}$ & $\begin{array}{c}\text { Equivalent in } \\
\text { oktas }\end{array}$ & $\begin{array}{c}\text { Cloud cover } \\
\text { fraction }\end{array}$ & ASOS note \\
\hline 00 to $\leqq 05$ & 0 & 0 & Clear \\
$>05$ to $\leqq 25$ & $>0$ to $2 / 8$ & 0.125 & Few \\
$>25$ to $\leqq 50$ & $>2 / 8$ to $\leqq 4 / 8$ & 0.375 & scattered \\
$>50$ to $\leqq 87$ & $>4 / 8$ to $\leqq 8 / 8$ & 0.75 & Broken \\
$>87$ to 100 & $8 / 8$ & 1.0 & overcast \\
\hline
\end{tabular}

Thus, in this study, the effects of seasonal variation and cloud cover on $\mathrm{LW}_{\mathrm{d}}$ were considered and a new land useadapted model developed. The objectives of this paper are (1) to analyze a yearly in situ downward longwave data and seasonal variation of $\mathrm{LW}_{\mathrm{d}}$ in yearly data based on wet and dry season for clear and all-sky $\mathrm{LW}_{\mathrm{d}}$ radiation models, (2) to compare cloud and land use factors as they affect $L_{\mathrm{d}}$ based on the dry season data, and (3) to develop land use-adapted all-sky $\mathrm{LW}_{\mathrm{d}}$ models based on dry and wet season data.

\section{Parameterization Schemes}

2.1. Basic Emissivity Model. Rizou and Nnadi [15] developed a land use-adapted model based on slab emissivity by Elachi [22]:

$$
\varepsilon_{s}=1-I_{0} e^{-\partial D}
$$

where $I_{0}$ is the incoming wave intensity, $\alpha$ is the total extinction coefficient (including absorption and emission), and $D$ is the slab thickness. The term $D$ is usually called the optical thickness or depth.

In their study, the authors suggested that either temperature or humidity parameters can capture all $\mathrm{LW}_{\mathrm{d}}$ over a wide range of climatic conditions because of the compensating effects of temperature and water vapor. Therefore, the following equation, which superpositioned the two effects in one equation, was generated for the daily $\mathrm{LW}_{\mathrm{dc}}$ :

$$
\begin{aligned}
\mathrm{Lw}_{\mathrm{dc}} & =\left(1-C_{1} e^{-T_{0} / C_{2}}+C_{3} e^{-e_{0} / C_{4}}\right) \sigma T^{4}, \\
\varepsilon_{s} & =\left(1-C_{1} e^{-T_{0} / C_{2}}+C_{3} e^{-e_{0} / C_{4}}\right),
\end{aligned}
$$

where $C_{1}, C_{2}, C_{3}$, and $C_{4}$ are site-specific constants and $\varepsilon_{s}$ is the emissivity of the atmosphere, $\sigma\left(=5.67 \times 10^{-8} \mathrm{~W} / \mathrm{m}^{2} \mathrm{~K}^{4}\right)$ 
TABLE 3: Comparison of $\mathrm{LW}_{\mathrm{d}}$ and cloud cover days in wet and dry season.

\begin{tabular}{|c|c|c|c|c|}
\hline \multicolumn{5}{|c|}{ Dry season $($ total days $=231)$} \\
\hline Site & Deland & Ocklawaha & Lindsey & Orange \\
\hline Land use type & $\begin{array}{c}\text { urban } \\
\text { (medium density) }\end{array}$ & wetland & agriculture & rangeland \\
\hline Average $\mathrm{LW}_{\mathrm{d}}$ radiation of all days $\left(\mathrm{Wm}^{-2}\right)$ & 349.10 & 338.81 & 349.09 & 332.86 \\
\hline Average cloud cover of all days & 0.27 & 0.26 & 0.28 & 0.28 \\
\hline Number of clear days & 36 days & 41 days & 20 days & 44 days \\
\hline \multicolumn{5}{|c|}{ Wet season $($ total days $=126)$} \\
\hline Site & Deland & Ocklawaha & Lindsey & Orange \\
\hline Land use type & $\begin{array}{c}\text { urban } \\
\text { (medium density) }\end{array}$ & wetland & agriculture & rangeland \\
\hline Average $L W_{d}$ radiation of all days $\left(\mathrm{Wm}^{-2}\right)$ & 414.13 & 404.32 & 407.55 & 402.55 \\
\hline Average cloud cover of all day & 0.32 & 0.31 & 0.31 & 0.35 \\
\hline Number of clear days & 0 days & 1 day & 1 day & 0 days \\
\hline
\end{tabular}

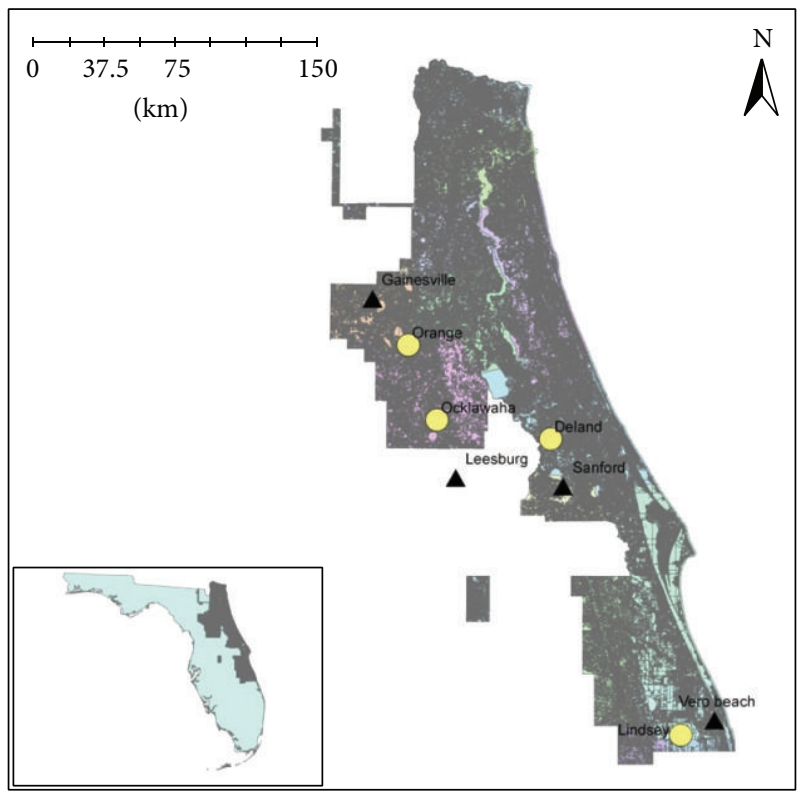

A Weather stations

CNR1

FIGURE 1: Location of the CNR1 and weather stations in the SJRWMD region.

is the Stefan-Boltzman constant, and $T$ is the air temperature. With the use of multiple nonlinear regression analysis, the values of the parameters were obtained for all sites. Because temperature and water vapor variation affect cloud cover, the present study developed a form of (2a) by considering seasonal variation and cloud effects.

2.2. Existing All-Sky Parameterizations. The presence of clouds results in warmer air temperatures and also increases the amount of longwave radiation reaching the earth surface. Therefore, various studies considered cloud effect in estimating downward longwave radiation $[1,4,12,14]$. Most of their approaches adjusted $\varepsilon_{s}$ for the fraction of cloud cover, $C$, to compute the increase in radiation. Equations (a) through (d) in Table 1 were developed for estimating all-sky downward longward radiation in which the cloud cover $C$ was based on human observations. In determining $C$, the sky condition was divided into 10 sectors and the fraction of 10 was used to estimate the cloud fraction [12]. However, in some study areas, the cloud cover data were absent due to lack of observers $[1,4,12,14]$. In their later study, Crawford and Duchon [1] generalized the effect of clouds, as shown in (3), by introducing a cloud fraction term clf, defined as clf $=1-s$, in which $s$ is the ratio of the measured solar irradiance to the clear-sky irradiance:

$$
\begin{aligned}
\operatorname{LW}_{\mathrm{d}}=\{\mathrm{clf} & +(1-\mathrm{clf}) \\
& \left.\times\left(1.22+0.06 \cdot \sin \left[(m+2) \cdot \frac{\pi}{6}\right]\right)\left(\frac{e}{T}\right)^{1 / 7}\right\} \sigma T^{4},
\end{aligned}
$$

where $m$ is the numerical month (e.g., January $=1$ ) and $e$ is the vapor pressure (mbar).

A general limitation and drawback of this approach are that it can only be used during the daylight hours. In order to avoid this limitation, this study uses the cloud fraction data of automated surface observing system (ASOS) for developing the all-sky $\mathrm{LW}_{\mathrm{d}}$ model. The cloud amount is determined by a laser beam ceilometer with a vertical range of $3600 \mathrm{~m}$ where the beam's width is $18 \mathrm{~m}$. The ASOS cloud sensor has a 0.9 microns wavelength, a nominal pulse frequency of $770 \mathrm{~Hz}$, and sampling frequency of $30 \mathrm{~s}$ with an average interval of $30 \mathrm{~min}$. Thus the daily average cloud cover is based on $30 \mathrm{~min}$ internal cloud cover. The cloud fraction is recorded in oktas with a maximum error of 5\% [23].

Table 2 shows ASOS cloud gradation used in this study to develop cloud cover fractions. Laser beam ceilometers have an advantage over human observers. Traditionally, observers must wait for their eyes to adapt to the dark before they are able to accurately distinguish nighttime sky condition, while 

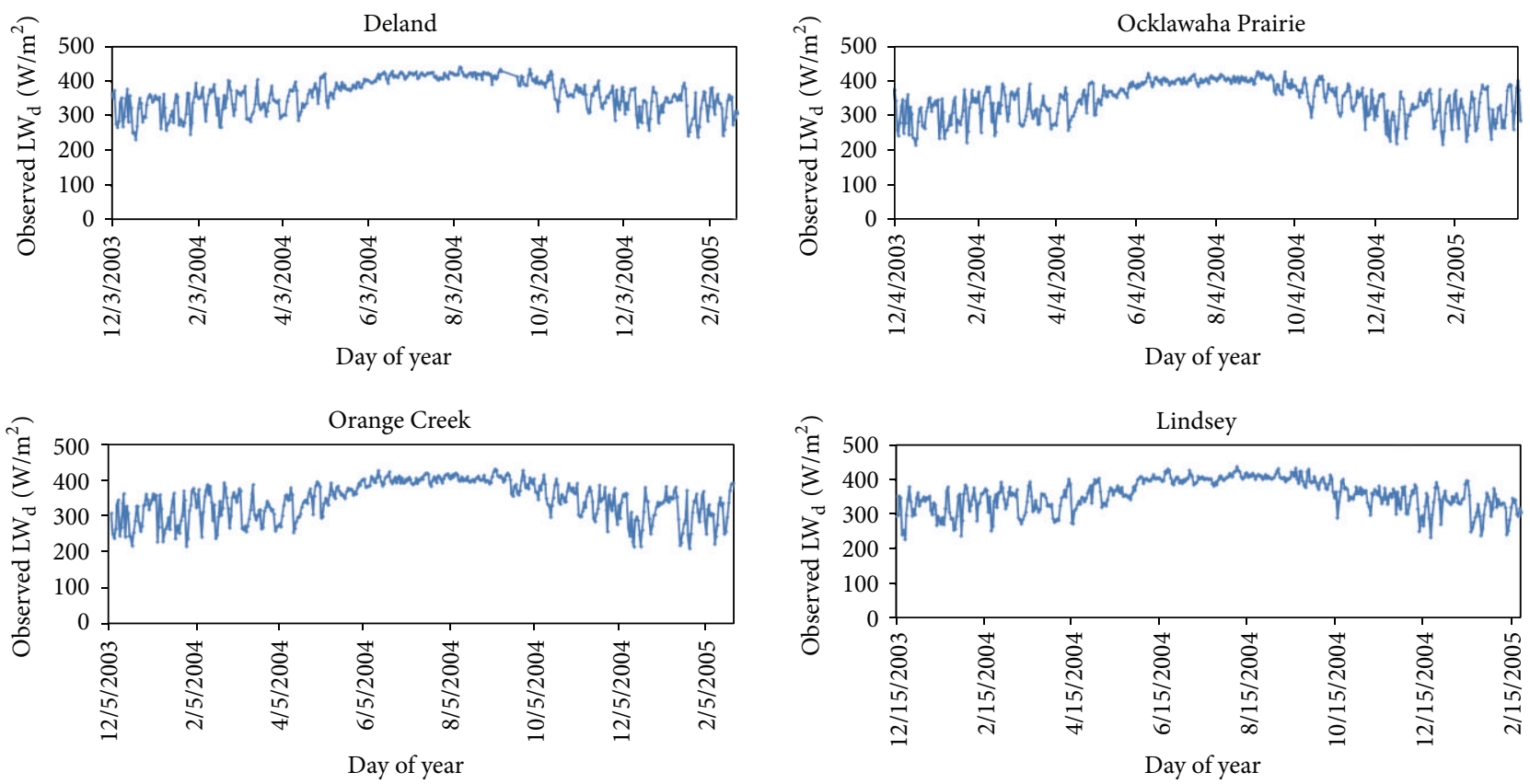

FIGURE 2: Seasonal variation of $\mathrm{LW}_{\mathrm{d}}$.

laser beam can adapt to night conditions. Another advantage of laser beam ceilometers is that it reports the onset of lower stratus moving over the ceilometer within $2 \mathrm{~min}$ and the formation/dissipation of a low ceiling within $10 \mathrm{~min}$ [23].

The equivalent oktas as defined by ASOS was further reduced to cloud cover fractions based on the average values (Table 2). Using the cloud cover fractions developed, the general form of all-sky $\mathrm{LW}_{\mathrm{d}}$ adjusted equation is given as

$$
\operatorname{Lw}_{\mathrm{d}}=\operatorname{Lw}_{\mathrm{dc}}\left(\alpha+C^{\beta}\right)
$$

where $C$ is cloud cover fractions and $\alpha, \beta$ in general depend on cloud characteristics, and with the use of multiple nonlinear regression analysis, the values of the parameters were obtained for all sites.

\section{Data Collection}

Daily data of year 2004 were utilized for model development. The data comprising of weather data (air temperature, dew point temperature, and cloud cover) were collected from National Climatic Data Center of National Oceanic and Atmospheric Administration (NOAA, accessed March 2005, http://www.ncdc.noaa.gov/oa/ncdc.html) and LW radiation from net radiometer (CNR1) at four sites within Saint Johns River Water Management District (SJRWMD). The LW radiation sites spread over latitudes of $27.58^{\circ} \mathrm{N}$ to $30.32^{\circ} \mathrm{N}$ and longitudes of $80.60^{\circ} \mathrm{W}$ to $82.07^{\circ} \mathrm{W}$ and represent different land uses (urban, agricultural, rangeland, forest, open water, and wetland), as shown in Figure 1. The weather data were collected from NOAA's weather stations in the vicinity of the CNR1 locations. The proximity of the weather stations to the CNR1 locations varies by $1^{\prime}-17^{\prime}$ latitude. The CNR1 stations in this study are Deland, Orange Creek, Ocklawaha, and
Lindsey Citrus. The Deland radiation station, which is located at a wastewater treatment plant surrounded by a paved road, grass, and shrubs, represents an urban land use. Orange Creek, which is covered by bahia grass, oak, and pine trees, represents a rangeland land use type. Ocklawaha is a wetland covered by willow, saw grass, cattail, lily pads, and wiregrass. Lindsey Citrus is an agricultural site with short grass beneath the tree canopy, which is under regular irrigation schedule.

At these sites, the longwave and shortwave radiation fluxes were measured by pyrgeometers (CG3 radiometers with spectral range $5-50 \mu \mathrm{m}$, by Kipp and Zonen) and pyranometers (CM3 radiometers, by Kipp and Zonen), respectively. The expected accuracy of the CG3 sensor has a limit of $\pm 10 \%$ for daily totals and $\pm 20 \mathrm{~W} / \mathrm{m}^{2}$ for individual measurements as provided by the manufacturer [24]. The steps of sensor calibration and the data quality assurance are listed below [15]. (1) We compared the simultaneous field measurements and reference sensor data twice a month. Measurements that differ more than $\pm 3 \%$ would be documented. (2) For consistency purpose, we also compared data from other regional sensors, including the incoming LW radiation data and incoming SW radiation data. If peaks in LW coincided with nadirs in SW radiation, it usually indicated a shadowing effect on the sensor. These data are removed from the dataset. (3) In addition, LW data are also compared with sensor temperature data and low battery voltage reports. When the sensor heater has been deactivated due to low battery reading, the LW data are compared with incoming SW data.

The ASOS HO-83 hygrothermometer was used for temperature measurements, which uses a resistive temperature device (root mean square errors (RMSE): $0.5^{\circ} \mathrm{C}$, max error: $\left.1^{\circ} \mathrm{C}\right)$ to measure air temperature, and a chilled mirror device (RMSE: $0.6-2.6^{\circ} \mathrm{C}$, max error: $1.1-4.4^{\circ} \mathrm{C}$ ) to measure dew 

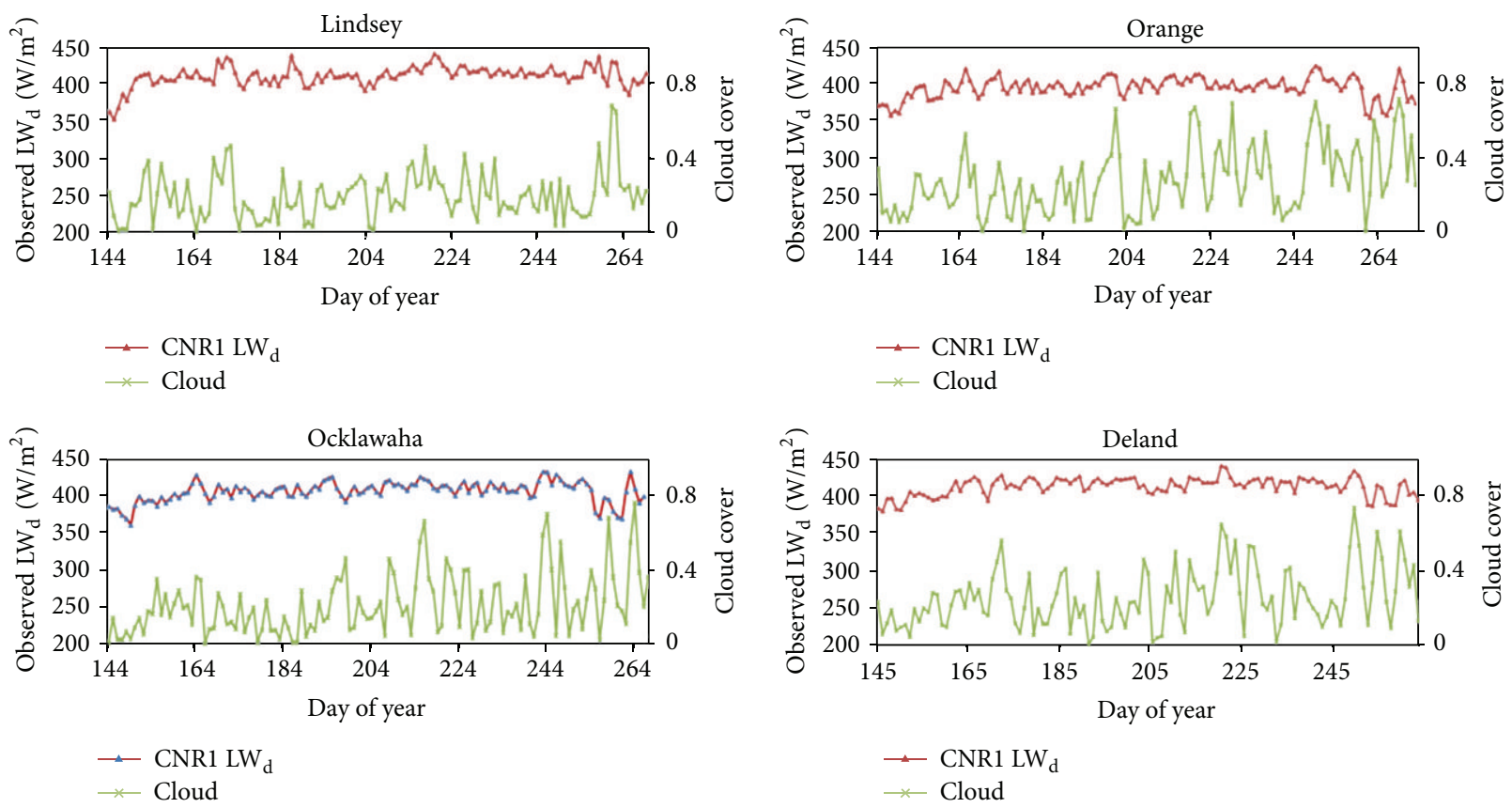

FIGURE 3: $\mathrm{LW}_{\mathrm{d}}$ and cloud cover during wet season.
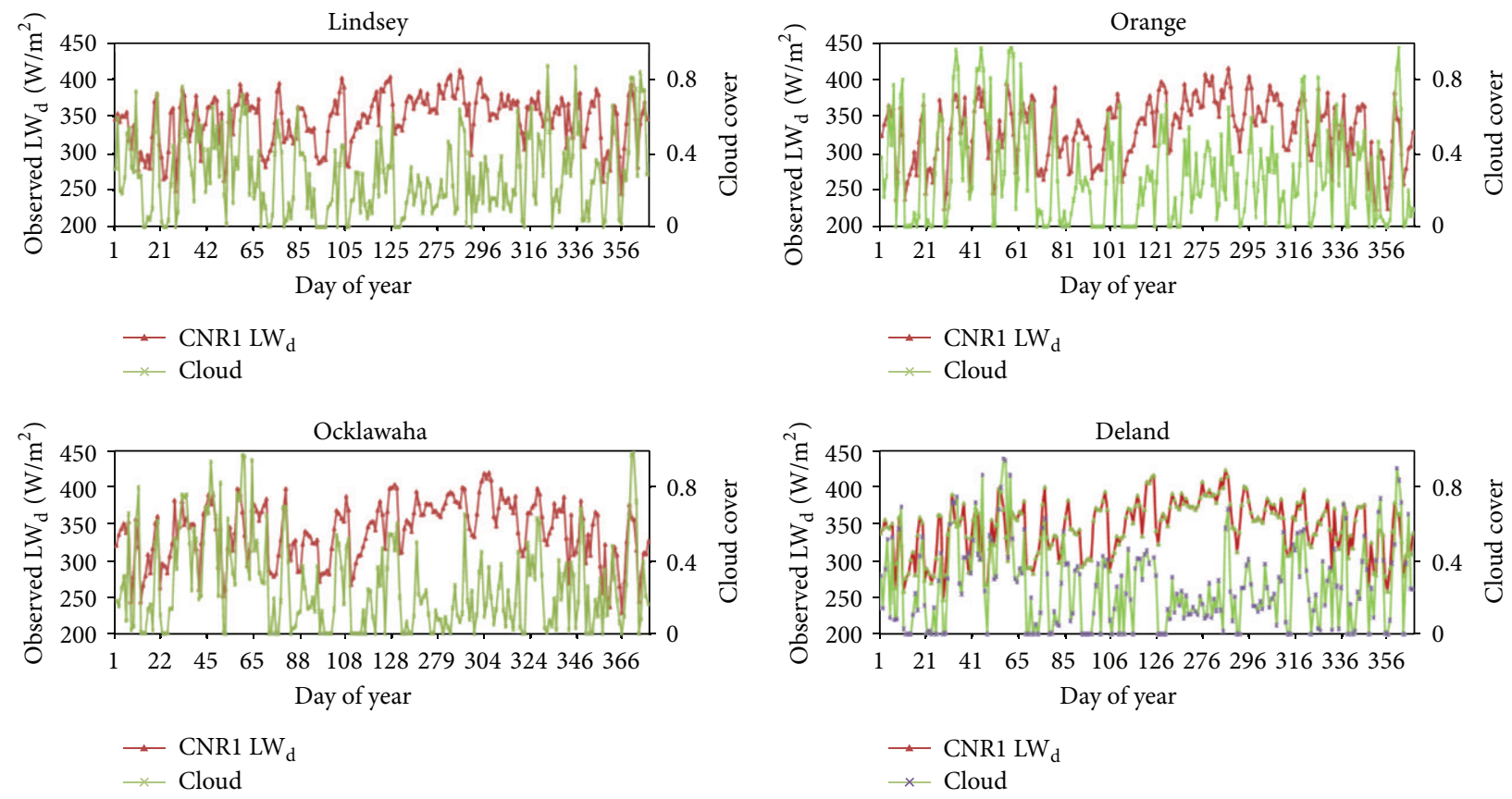

FIGURE 4: $\mathrm{LW}_{\mathrm{d}}$ and cloud cover during dry season.

point temperature. The sampling frequency for both devices is one minute with averaging interval of 5 minutes. Water vapor pressure data were obtained by daily averaging of the dew point temperature from NOAA data. The water vapor pressure at the surface was calculated using (5) [25]:

$$
e_{0}=6.1078 \times 10^{7.5 T_{d} /\left(T_{d}+287.3\right)},
$$

where $e_{0}(\mathrm{hPa})$ is the actual water vapor pressure at the surface and $T_{d}\left({ }^{\circ} \mathrm{C}\right)$ is the dew point temperature.
Model validation data were obtained from surface exchange (SURFX) sites located at Bondville, Illinois $\left(40.01^{\circ} \mathrm{N}, 88.29^{\circ} \mathrm{W}\right)$, which represents an agricultural setting with corn and soybeans. SURFX sites are part of Global Energy and Water Cycle Experiment (GEWEX) America Prediction Project (GAPP) program for an agricultural area. Data collected at the SURFX sites, which include energy fluxes, carbon, and surface meteorology, were obtained from http://www.joss.ucar.edu/ghp/ceopdm/archive/eop1_data 


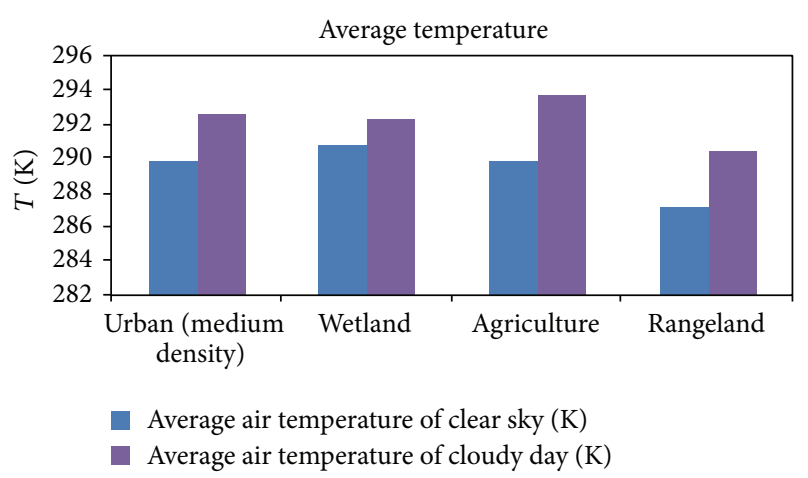

Figure 5: Average daily temperature in dry season.

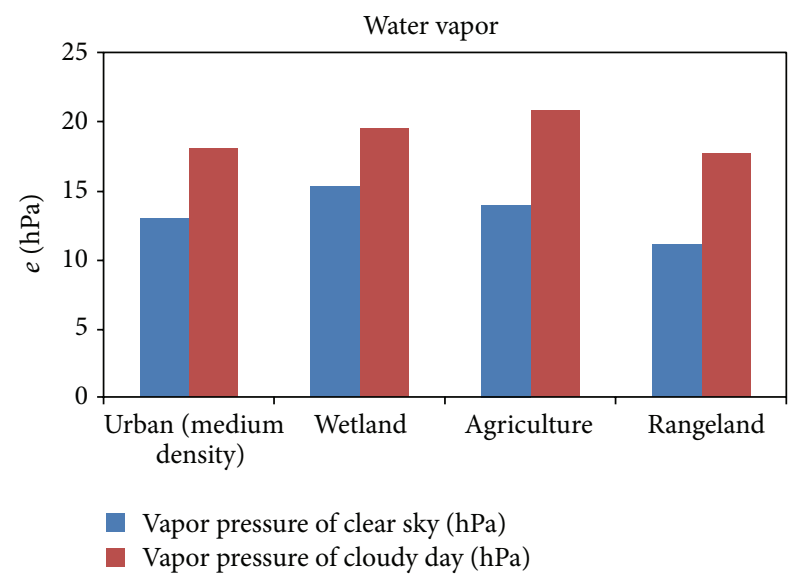

FIgURE 6: Average water vapor in dry season.

from July through September 2001. The cloud cover data were obtained from the nearest NOAA station located at Champaign/Urbana Willard Airport and have an elevation of $230 \mathrm{~m}$ a.s.l [15].

\section{Results}

4.1. Seasonal Variation. The wet season in Florida starts from end of May to middle of October while the rest is classified as dry season. The longwave radiation is higher and stable during wet season and lower with relative large variation during the dry season. Figure 2 shows the observed downward longwave radiation seasonal variation for all land uses. The $\mathrm{LW}_{\mathrm{d}}$ ranges from 230 to $440 \mathrm{Wm}^{-2}$ in the four sites in the study area during the year 2004. The $\mathrm{LW}_{\mathrm{d}}$ ranged from 381 to $441 \mathrm{Wm}^{-2}, 363$ to $432 \mathrm{Wm}^{-2}, 359$ to $431 \mathrm{Wm}^{-2}$, and 349 to $436 \mathrm{Wm}^{-2}$, in Deland, Orange Creek, Ocklawaha Prairie, and Lindsey Citrus, respectively, during the wet season. The $\mathrm{LW}_{\mathrm{d}}$ in city of Deland (urban area), Orange Creek (rangeland), Ocklawaha Prairie (wetland), and Lindsey Citrus (agriculture), varied from $233 \mathrm{Wm}^{-2}$ to $441 \mathrm{Wm}^{-2}, 224 \mathrm{Wm}^{-2}$ to $431 \mathrm{Wm}^{-2}, 219 \mathrm{Wm}^{-2}$ to $432 \mathrm{Wm}^{-2}$, and $241 \mathrm{Wm}^{-2}$ to $438 \mathrm{Wm}^{-2}$, respectively. during the dry season. Figure 3 presents the $\mathrm{LW}_{\mathrm{d}}$ and cloud cover in the four land use sites during wet season, while Figure 4 provides

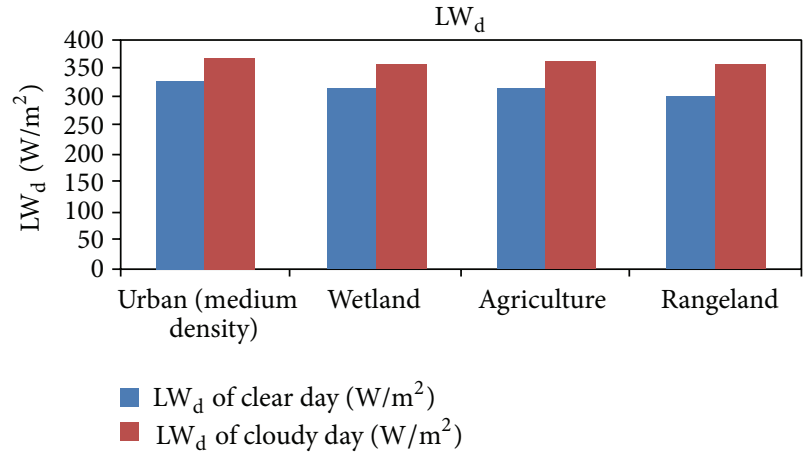

Figure 7: $\mathrm{LW}_{\mathrm{d}}$ of different land use sites in the dry season.

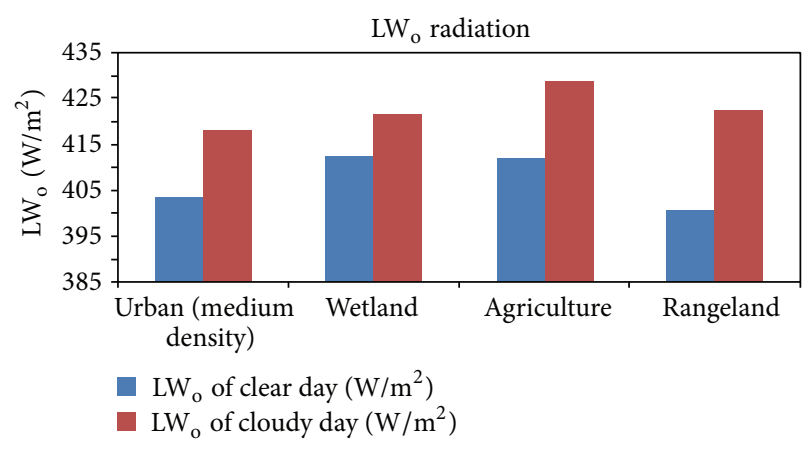

Figure 8: $\mathrm{LW}_{\mathrm{o}}$ in dry season.

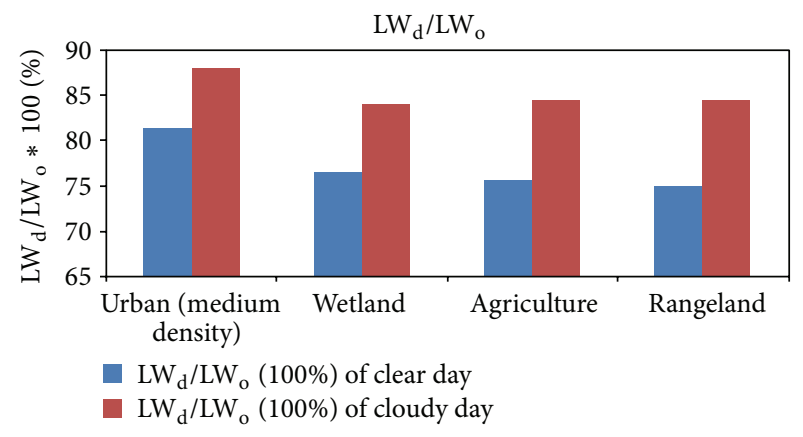

FIgURE 9: Ratio of $\mathrm{LW}_{\mathrm{d}}$ to $\mathrm{LW}_{\mathrm{o}}$ in dry season.

the $\mathrm{LW}_{\mathrm{d}}$ and cloud cover of the four sites over the study period in dry season. $\mathrm{LW}_{\mathrm{d}}$ in all the four sites showed positive correlation with the cloud cover in wet season; however, this relationship is not as significant as that of dry season because there are only few clear sky days during wet season, as shown in Table 3, while there were more than 20 days of clear sky $(c=0)$ during the dry season. It can be seen that the cloud cover strongly affects $\mathrm{LW}_{\mathrm{d}}$, while in clear sky condition, the $\mathrm{LW}_{\mathrm{d}}$ had lower values, which dropped significantly and approached its lowest value. This variation is obviously much smaller in wet season than the dry season.

4.2. Factors Affecting Downward Longwave Radiation in Dry Season. The average air temperature and water vapor pressure on cloudy days were observed to be higher than 
TABLE 4: New all-sky $L_{d}$ equations for four land use sites during dry season.

\begin{tabular}{llr}
\hline Parameterization & Experimental site & Equation \\
\hline $\mathrm{LW}_{\mathrm{dc}}=\left(1-\left(-4.575 \times e^{-T_{0} / e^{94.856}}+0.576 \times e^{-e_{0} / 42.409}\right) \sigma T^{4}\right.$ & City of Deland (USA) \\
$\mathrm{LW}_{\mathrm{d}}=\mathrm{LW}_{\mathrm{dc}} \times\left(1+0.222 \times C^{1.753}\right)$ & \\
$\mathrm{Lw}_{\mathrm{dc}}=\left(1-\left(-19.087 \times e^{-T_{0} / 66.064}+0.658 \times e^{-e_{0} / 36.520}\right) \sigma T^{4}\right.$ & Orange Creek (USA) \\
$\mathrm{LW}_{\mathrm{d}}=\mathrm{LW}_{\mathrm{dc}} \times\left(1+0.249 \times C^{1.884}\right)$ & \\
$\mathrm{LW}_{\mathrm{dc}}=\left(1-\left(-61.037 \times e^{-T_{0} / 58.424}+0.905 \times e^{-e_{0} / 44.482}\right) \sigma T^{4}\right.$ & \\
$\mathrm{LW}_{\mathrm{d}}=\mathrm{Lw}_{\mathrm{dc}} \times\left(1+0.194 \times C^{1.425}\right)$ & Ocklawaha Prairie (USA) \\
$\mathrm{Lw}_{\mathrm{dc}}=\left(1-\left(-100.719 \times e^{-T_{0} / 43.942}+0.555 \times e^{-e_{0} / 34.988}\right) \sigma T^{4}\right.$ & \\
$\mathrm{LW}_{\mathrm{d}}=\mathrm{Lw}_{\mathrm{dc}} \times\left(1+0.219 \times C^{1.556}\right)$ & Lindsey Citrus (USA) \\
\hline
\end{tabular}
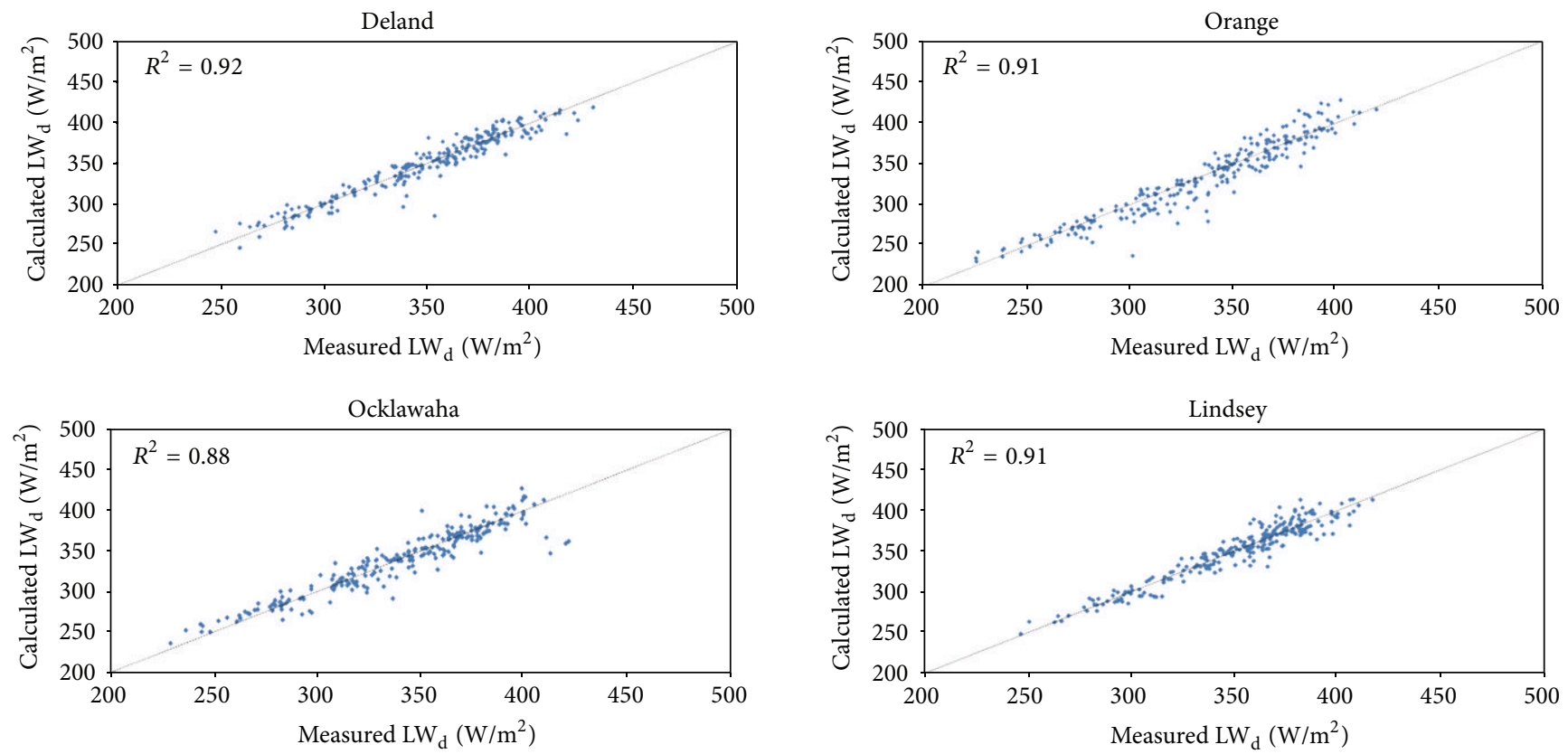

FiguRE 10: Comparison of new $\mathrm{LW}_{\mathrm{d}}$ models for all-sky and observed data in dry season.

those in clear sky days. Figures 5 and 6 show the average daily air temperature and water vapor pressure, respectively, at the study sites during the dry season. During the clear sky days, the wetland had the smallest surface albedo (about 0.03 0.1 for small zenith angle, [26]), which resulted in the highest temperature and water vapor pressure. However, as cloud cover is a kind of albedo $(0.6 \sim 0.9$, [26]), when combined with the other surface albedo can affect surface air temperature. Thus the agricultural area shows the highest temperature and water vapor pressure in cloud days. This could be explained by the fact that under cloudy condition, albedo of soils and vegetation are decreased thus resulting in higher temperature and water vapor. High albedo of the rangeland area $(0.26,[26])$ resulted in low temperature and low water vapor pressure under all-sky conditions.

Figure 7 shows the $\mathrm{LW}_{\mathrm{d}}$ from four different land use sites in the dry season with the largest on the urban area and the smallest on the rangeland area in both clear sky and cloudy conditions. Considering the effect of outward longwave radiation $\left(\mathrm{LW}_{\mathrm{o}}\right)$, which is the solar radiation absorbed by the earth that causes the planet to heat up and emit radiation, it can be observed that the agriculture area had the largest $\mathrm{LW}_{\mathrm{o}}$ while rangeland area had the smallest $\mathrm{LW}_{\mathrm{o}}$. Figure 8 compares $\mathrm{LW}_{\mathrm{o}}$ and $\mathrm{LW}_{\mathrm{d}}$ on the four different land use sites in dry season, while Figure 9 shows the ratio of $\mathrm{LW}_{d}$ to $\mathrm{LW}_{\mathrm{o}}$. Because under clear sky condition a significant fraction of the longwave radiation emitted from the surface is absorbed by trace gases and suspended particles in the air, therefore, the urban area had the largest value of $\mathrm{LW}_{\mathrm{d}} / \mathrm{LW}_{\mathrm{o}}$, compared to the other three land use areas. This condition results in atmospheric greenhouse effect.

Also in Figure 6 the relationship between water vapor and $\mathrm{LW}_{\mathrm{d}}$ under clear sky condition suggests that though the water vapor in the urban area was lower than the other areas but $\mathrm{LW}_{\mathrm{d}}$ was larger. This suggests that (1) the geometry of city streets absorbs more shortwave radiation and makes longwave radiation be exchanged between buildings rather than lost to the sky, (2) the concrete structures especially 
TABLE 5: Comparison of model predictions with observed all-sky $\mathrm{LW}_{\mathrm{d}}$ data in dry season.

\begin{tabular}{|c|c|c|c|c|c|}
\hline \multirow[b]{2}{*}{ Statistical performance } & \multicolumn{5}{|c|}{ Model } \\
\hline & New & $\begin{array}{c}\text { Maykut and } \\
\text { Church [7] }\end{array}$ & Jacobs $[8]$ & $\begin{array}{c}\text { Sugita and } \\
\text { Brutsaert [20] }\end{array}$ & Duarte et al. [12] \\
\hline \multicolumn{6}{|c|}{ City of Deland } \\
\hline BIAS $\left(\mathrm{Wm}^{-2}\right)$ & -0.18 & -5.42 & 7.05 & -10.09 & 22.37 \\
\hline $\operatorname{RMSE}\left(\mathrm{Wm}^{-2}\right)$ & 10.81 & 12.78 & 13.86 & 18.54 & 27.86 \\
\hline $\operatorname{MAE}\left(\mathrm{Wm}^{-2}\right)$ & 8.00 & 9.26 & 10.99 & 13.15 & 24.00 \\
\hline PMRE (\%) & 2.30 & 2.64 & 3.14 & 3.70 & 6.77 \\
\hline \multicolumn{6}{|c|}{ Orange Creek } \\
\hline BIAS $\left(\mathrm{Wm}^{-2}\right)$ & -2.61 & -8.06 & 2.78 & -14.10 & 16.35 \\
\hline RMSE $\left(\mathrm{Wm}^{-2}\right)$ & 14.45 & 16.22 & 15.99 & 23.71 & 25.85 \\
\hline $\operatorname{MAE}\left(\mathrm{Wm}^{-2}\right)$ & 10.64 & 12.27 & 12.31 & 16.90 & 20.48 \\
\hline PMRE (\%) & 3.19 & 3.67 & 3.63 & 4.95 & 5.91 \\
\hline \multicolumn{6}{|c|}{ Lindsey Citrus } \\
\hline BIAS $\left(\mathrm{Wm}^{-2}\right)$ & -0.07 & -7.27 & 6.01 & -11.76 & 22.33 \\
\hline $\operatorname{RMSE}\left(\mathrm{Wm}^{-2}\right)$ & 10.53 & 13.86 & 12.64 & 19.44 & 26.66 \\
\hline $\operatorname{MAE}\left(\mathrm{Wm}^{-2}\right)$ & 8.03 & 10.55 & 9.93 & 14.40 & 22.97 \\
\hline PMRE (\%) & 2.27 & 2.95 & 2.81 & 4.00 & 6.46 \\
\hline \multicolumn{6}{|c|}{ Ocklawaha Prairie } \\
\hline BIAS $\left(\mathrm{Wm}^{-2}\right)$ & -0.62 & -6.10 & 4.60 & -10.94 & 18.45 \\
\hline RMSE $\left(\mathrm{Wm}^{-2}\right)$ & 13.97 & 15.71 & 15.27 & 20.81 & 25.86 \\
\hline $\operatorname{MAE}\left(\mathrm{Wm}^{-2}\right)$ & 9.76 & 11.10 & 11.58 & 14.99 & 21.72 \\
\hline PMRE (\%) & 2.87 & 3.41 & 3.23 & 4.30 & 6.34 \\
\hline
\end{tabular}

TABLE 6: Statistical analysis for model verification and validation.

\begin{tabular}{|c|c|c|c|c|c|}
\hline \multirow{2}{*}{ Statistical performance } & \multicolumn{5}{|c|}{ Model } \\
\hline & New & Maykut and Church [7] & Jacobs $[8]$ & Sugita and Brutsaert [20] & Duarte et al. [12] \\
\hline \multicolumn{6}{|c|}{ City of Bondville } \\
\hline BIAS $\left(\mathrm{Wm}^{-2}\right)$ & -2.80 & -9.10 & 2.86 & -12.54 & 18.58 \\
\hline $\operatorname{RMSE}\left(\mathrm{Wm}^{-2}\right)$ & 10.82 & 14.90 & 10.95 & 19.24 & 22.95 \\
\hline $\operatorname{MAE}\left(\mathrm{Wm}^{-2}\right)$ & 8.91 & 12.01 & 8.95 & 15.44 & 19.58 \\
\hline PMRE (\%) & 2.51 & 3.36 & 2.50 & 4.27 & 5.35 \\
\hline
\end{tabular}

paved roads as well as the high density of industrial processes in the urban environment are favorable for pollution and dust release, and (3) longwave radiation trapped in the polluted urban atmosphere leads to the urban greenhouse effect [27].

4.3. All-Sky $L W_{d}$ Model Calibration for Dry Season. In this section, the general form of land use-adapted model, equation (4) was used in developing all-sky $\mathrm{LW}_{\mathrm{d}}$ at the land use sites in the dry season. Clear sky data obtained from CNR1 were used to determine the coefficients for $L_{\mathrm{dc}}$ in $(2 \mathrm{a})$ and (2b). Using observed data for all-sky condition during dry season and (2a) and (2b) with cloud cover data the coefficients and were determined from (4) for all land use areas as shown in (e) through (1) (Table 4). In Figure 10 the new all-sky LW $_{d}$ model is verified by comparing $\mathrm{LW}_{\mathrm{d}}$ data obtained from measurements over the study area. The results show that the new all-sky $\mathrm{LW}_{\mathrm{d}}$ models closely predict the measured data with $R^{2}$ values between 0.88 and 0.92 for all land use areas studied.

These models were compared to four existing models for all-sky conditions $[7,8,12,20]$ as shown in Table 5 . The new and existing modes used (2a) and (2b) for calculating $L_{\mathrm{dc}}$, and in the Rizou and Nnadi' study [15], they proved that land use adapted $\mathrm{LW}_{\mathrm{dc}}$ had the better statistical performances than the existing models, including Jacobs [8], Maykut and Church [7], Sugita and Brutsaert [20], and Duarte [12]. Statistical evaluation of the performance of these models suggested that the new all-sky model gave the smallest values for the BIAS, RMSE, MAE, and PMRE (Table 5). Amongst the four existing models, Jacobs's [8] model had the best performance on the rangeland area but the worst on the urban area, while Maykut 
and Sugita's model had the best performance on the urban but the worst on the rangeland area and Duarte's [12] model had the worst performances of the four different land use areas.

In validating the new all-sky models, an agricultural land use area under all-sky conditions at Bondville, Illinois, was selected. The new agricultural land use clear sky model (Equation (k) in Table 4) was used to determine $\mathrm{LW}_{\mathrm{dc}}$ and the cloud coverage data was obtained from the nearest NOAA station, located at Champaign/Urbana Willard Airport, while equation (l) was used to calculate all-sky $\mathrm{LW}_{\mathrm{d}}$. Figure 11 shows that the new all-sky model had a very good fit with the data with $R^{2}$ value of 0.93 . The four existing models were also compared to the observed data from Bondville, Illinois. The statistical results show that these models performed poorly as shown in Table 6 . The poor performance could be attributed to the fact that these models did not consider effects of land use in their development. Hence, land use is an important factor in developing all-sky $\mathrm{LW}_{\mathrm{d}}$. Figure 2 and Table 3 show that, in the wet season, the $\mathrm{LW}_{\mathrm{d}}$ was higher with much fewer days of clear sky compared to the dry season. The fact that there was only one or no clear sky day at all the four sites during wet season indicates that it was unnecessary and impossible to calculate the $\mathrm{LW}_{\mathrm{dc}}$ accurately. However, $\mathrm{LW}_{\mathrm{dc}}$ is needed for the calculation of $\mathrm{LW}_{\mathrm{d}}$ under all-sky condition, as shown in (4). In order to overcome this difficulty, the initial approach was to substitute the values of temperature and water vapor in wet season into dry season model under clear sky condition to come up with $\mathrm{LW}_{\mathrm{dc}}$ and then substitute in the $\mathrm{LW}_{\mathrm{d}}$ model to generate wet season model under all-sky conditions using (4). The statistical results of this analysis are presented in Table 7. It can be seen that the errors were higher than those obtained in dry season condition.

4.4. All-Sky $L W_{d}$ in Wet Season. Another approach was proposed in this study where a term called pseudo- $\mathrm{LW}_{\mathrm{dc}}$ was introduced. The pseudo- $\mathrm{LW}_{\mathrm{dc}}$ is defined as a longwave radiation value during wet season when the cloud coverage equals a certain cut-off value that is small enough but can assure enough observation data for the regression of (2a) and ( $2 \mathrm{~b}$ ), for example, 10 percentile of the whole observation cloud coverage data such that (4) would be applicable to cases where cloud coverage is larger than the cut-off value for the pseudo- $\mathrm{LW}_{\mathrm{c}}$. In this study, a cut-off cloud coverage value of 0.1 was used to define the pseudo- $\mathrm{LW}_{\mathrm{dc}}$ giving clear sky days in the observed data to be 22, 24, 30, and 39 days for agriculture, rangeland, wetland, and urban area, respectively. The all-sky $L_{\mathrm{d}}$ models for wet season generated based on pseudo- $-\mathrm{LW}_{\mathrm{dc}}$ are given in equation $(\mathrm{m})$ through $(\mathrm{t})$ for all land use areas considered as shown in Table 8.

The results and the statistical analysis are presented in Figure 12 and Table 9, respectively. The statistics by the new model following the pseudo- $\mathrm{LW}_{\mathrm{dc}}$ approach gave the smallest values when compared to the existing four models as shown in Table 9, therefore suggesting that this approach provided a better prediction except for the agricultural area. The discrepancy could be attributed to improper selection of the cut-off value of cloud coverage for the pseudo- $\mathrm{LW}_{\mathrm{dc}}$. As addressed above the modified equation (4) is mainly

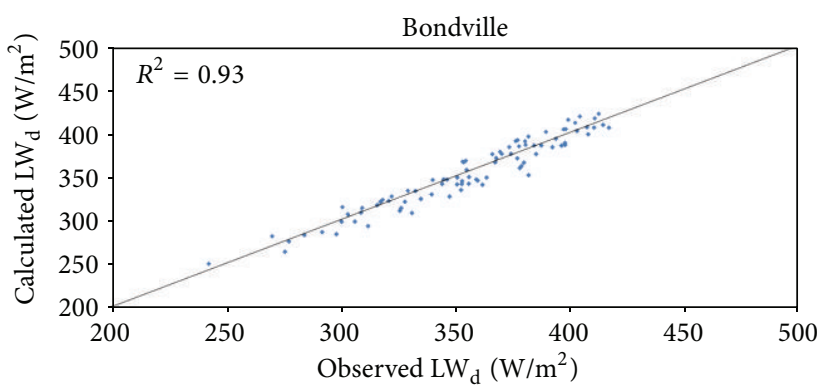

FIGURE 11: Validation of all-sky $\mathrm{LW}_{\mathrm{d}}$ at Bondville, IL.

TABLE 7: Statistical performance of the $L_{\mathrm{d}}$ dry season models tested for wet season.

\begin{tabular}{lcc}
\hline Statistical performance & $\begin{array}{c}\text { Model } \\
\text { Dry season model }\end{array}$ \\
\hline & City of Deland & \\
BIAS $\left(\mathrm{Wm}^{-2}\right)$ & 4.38 \\
RMSE $\left(\mathrm{Wm}^{-2}\right)$ & 10.46 \\
MAE $\left(\mathrm{Wm}^{-2}\right)$ & 8.05 \\
PMRE $(\%)$ & 1.94 \\
\hline & & \\
BIAS $\left(\mathrm{Wm}^{-2}\right)$ & Orange Creek & 11.58 \\
RMSE $\left(\mathrm{Wm}^{-2}\right)$ & & 17.14 \\
MAE $\left(\mathrm{Wm}^{-2}\right)$ & & 13.94 \\
PMRE $(\%)$ & 3.46 \\
\hline & & \\
BIAS $\left(\mathrm{Wm}^{-2}\right)$ & Lindsey Citrus & -3.19 \\
RMSE $\left(\mathrm{Wm}^{-2}\right)$ & & 10.43 \\
MAE $\left(\mathrm{Wm}^{-2}\right)$ & & 6.46 \\
PMRE $(\%)$ & & 1.61 \\
\hline & & \\
BIAS $\left(\mathrm{Wm}^{-2}\right)$ & Ocklawaha Prairie & 2.94 \\
RMSE $\left(\mathrm{Wm}^{-2}\right)$ & & 18.54 \\
MAE $\left(\mathrm{Wm}^{-2}\right)$ & & 10.25 \\
PMRE $(\%)$ & & 2.52 \\
\hline
\end{tabular}

applicable when the cloud cover is larger than the cut-off value. As shown in Figure 4, Lindsey Citrus site has fewer days with cloud coverage larger than the cut-off value in wet season; hence, the amount of data used to estimate pseudo$\mathrm{LW}_{\mathrm{dc}}$ is limited, which in turn affected prediction ability of $\mathrm{LW}_{\mathrm{d}}$. Hence, sites with more days with cloud have better prediction.

\section{Summary and Conclusions}

Analysis of the observed $\mathrm{LW}_{\mathrm{d}}$ data in 2004 showed seasonal variation on different land use, suggesting that $\mathrm{LW}_{\mathrm{d}}$ have higher values and are stable during wet season and lower values with relatively large variation during dry season. Because of the variation in the dry season, the $\mathrm{LW}_{\mathrm{d}}$ data was used to compare factors affecting $\mathrm{LW}_{\mathrm{d}}$ radiation such as temperature, water vapor pressure, cloud cover, and land 
TABLE 8: All-sky $\mathrm{LW}_{\mathrm{d}}$ parameterizations for wet season.

\begin{tabular}{|c|c|c|}
\hline Parameterization & Experimental site & Equation \\
\hline pseudo $\mathrm{Lw}_{\mathrm{dc}}=\left(1-\left(-21.29 \times e^{-T_{0} / e^{52}}+0.30 \times e^{-e_{0} / 15}\right) \sigma T^{4}\right.$ & & $(\mathrm{m})$ \\
\hline $\mathrm{LW}_{\mathrm{d}}=\mathrm{LW}_{\mathrm{dc}} \times\left(1+0.087 \times C^{1.665}\right)$ & The city of Deland (USA) & (n) \\
\hline pseudo $\mathrm{Lw}_{\mathrm{dc}}=\left(1-\left(-22.43 \times e^{-T_{0} / e^{88.24}}+1.19 \times e^{-e_{0} / 82.68}\right) \sigma T^{4}\right.$ & & (o) \\
\hline $\mathrm{LW}_{\mathrm{d}}=\mathrm{LW}_{\mathrm{dc}} \times\left(1+0.173 \times C^{3.83}\right)$ & Orange Creek (USA) & $(\mathrm{p})$ \\
\hline pseudo $\mathrm{LW}_{\mathrm{dc}}=\left(1-\left(-182.78 \times e^{-T_{0} / e^{60.12}}+1.63 \times e^{-e_{0} / 151.02}\right) \sigma T^{4}\right.$ & & (q) \\
\hline $\mathrm{LW}_{\mathrm{d}}=\mathrm{LW}_{\mathrm{dc}} \times\left(1+0.037 \times C^{1.969}\right)$ & Ocklawaha Prairie (USA) & $(\mathrm{r})$ \\
\hline pseudo $\mathrm{Lw}_{\mathrm{dc}}=\left(1-\left(-46379.7 \times e^{-T_{0} / e^{25}}+1.12 \times e^{-e_{0} / 28.18}\right) \sigma T^{4}\right.$ & & (s) \\
\hline $\mathrm{LW}_{\mathrm{d}}=\mathrm{LW}_{\mathrm{dc}} \times\left(1+0.098 \times C^{0.845}\right)$ & Lindsey Citrus (USA) & $(\mathrm{t})$ \\
\hline
\end{tabular}

TABLE 9: Comparison of model predictions with observed all-sky $L_{\mathrm{d}}$ data in wet season.

\begin{tabular}{|c|c|c|c|c|c|}
\hline \multirow{2}{*}{ Statistical performance } & \multicolumn{5}{|c|}{ Model } \\
\hline & New & Maykut and Church [7] & Jacobs $[8]$ & Sugita and Brutsaert [20] & Duarte et al. [12] \\
\hline \multicolumn{6}{|c|}{ City of Deland } \\
\hline BIAS $\left(\mathrm{W} / \mathrm{m}^{2}\right)$ & 0.15 & -0.02 & 16.50 & -3.02 & 37.91 \\
\hline $\operatorname{RMSE}\left(\mathrm{W} / \mathrm{m}^{2}\right)$ & 7.34 & 7.79 & 20.01 & 8.45 & 40.63 \\
\hline $\operatorname{MAE}\left(\mathrm{W} / \mathrm{m}^{2}\right)$ & 5.92 & 6.22 & 16.95 & 6.65 & 37.93 \\
\hline PMRE (\%) & 1.43 & 1.50 & 4.09 & 1.59 & 9.15 \\
\hline \multicolumn{6}{|c|}{ Orange Creek } \\
\hline BIAS $\left(\mathrm{W} / \mathrm{m}^{2}\right)$ & -0.17 & 3.32 & 20.30 & -0.88 & 41.41 \\
\hline $\operatorname{RMSE}\left(\mathrm{W} / \mathrm{m}^{2}\right)$ & 9.36 & 10.90 & 25.28 & 9.70 & 45.39 \\
\hline $\operatorname{MAE}\left(\mathrm{W} / \mathrm{m}^{2}\right)$ & 7.10 & 8.40 & 21.52 & 7.34 & 41.52 \\
\hline PMRE (\%) & 1.76 & 2.08 & 5.31 & 1.82 & 10.27 \\
\hline \multicolumn{6}{|c|}{ Lindsey Citrus } \\
\hline BIAS $\left(\mathrm{W} / \mathrm{m}^{2}\right)$ & -0.37 & -7.03 & 6.15 & -8.40 & 25.60 \\
\hline $\operatorname{RMSE}\left(\mathrm{W} / \mathrm{m}^{2}\right)$ & 13.23 & 15.05 & 15.34 & 16.15 & 30.31 \\
\hline $\operatorname{MAE}\left(\mathrm{W} / \mathrm{m}^{2}\right)$ & 8.57 & 10.29 & 11.04 & 11.43 & 27.03 \\
\hline PMRE (\%) & 2.11 & 2.52 & 2.72 & 2.79 & 6.63 \\
\hline \multicolumn{6}{|c|}{ Ocklawaha Prairie } \\
\hline BIAS $\left(\mathrm{W} / \mathrm{m}^{2}\right)$ & 0.28 & 2.52 & 16.34 & 0.14 & 35.90 \\
\hline $\operatorname{RMSE}\left(\mathrm{W} / \mathrm{m}^{2}\right)$ & 8.36 & 10.11 & 21.61 & 8.37 & 40.15 \\
\hline $\operatorname{MAE}\left(\mathrm{W} / \mathrm{m}^{2}\right)$ & 6.22 & 7.24 & 17.16 & 6.23 & 35.77 \\
\hline PMRE (\%) & 1.56 & 1.81 & 4.25 & 156 & 8.84 \\
\hline
\end{tabular}

use. Since different land use has different albedo in relation to energy and water budget, the effects of temperature and water vapor pressure on various land use were evaluated using the albedo. The results of the analysis suggested that (1) the wetland area had the smaller albedo resulting in the higher temperature and water vapor pressure in the clear sky condition, whereas the rangeland had the higher albedo leading to lower temperature and water vapor pressure in allsky conditions and (2) the $\mathrm{LW}_{\mathrm{d}}$ at the four sites investigated varied with larger values in the urban area and smaller value in the rangeland land in both clear and cloud sky conditions.

Based on the seasonal variation dry and wet season data were separated and used for developing $\mathrm{LW}_{\mathrm{d}}$ models for different land use under all-sky conditions. This approach enhanced the models suitable for dry season and wet season prediction. The dry season models for the land use areas investigated performed better than existing models for $\mathrm{LW}_{\mathrm{d}}$ under all-sky condition as indicated by the statistical analysis of the results. However, the wet season models did not do as well as the dry season models. The low performance of the wet season models could be explained by the presence of one or no clear sky day condition at all the four sites, which made it difficult to calculate the $\mathrm{LW}_{\mathrm{dc}}$ accurately; therefore, developing a wet season model for $\mathrm{LW}_{\mathrm{d}}$ was challenging. To overcome this difficulty, a term, pseudo- $\mathrm{LW}_{\mathrm{dc}}$, was introduced to replace $L_{\mathrm{dc}}$ in all-sky model (4). This 

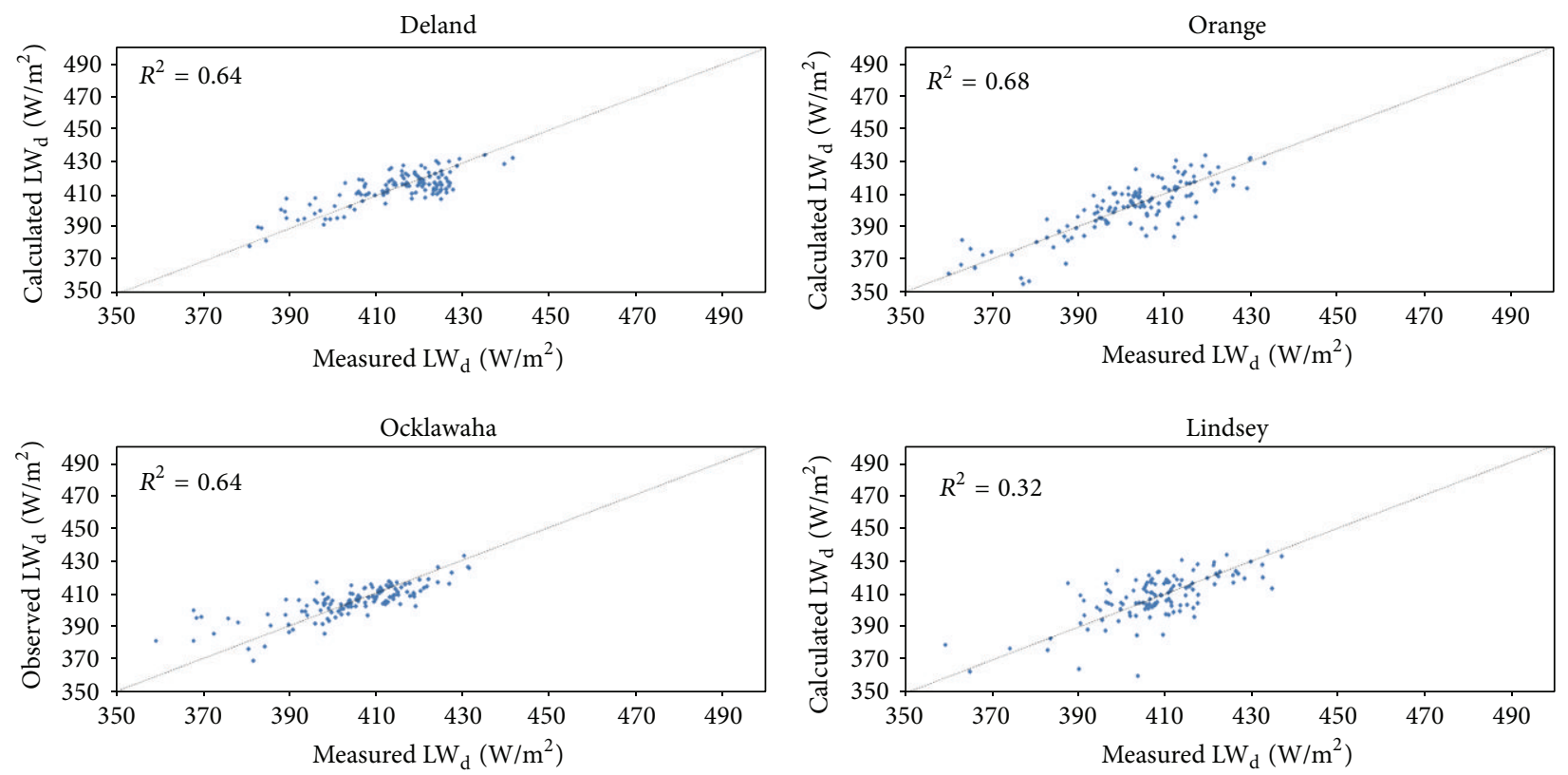

FIGURE 12: Comparison of new $\mathrm{LW}_{\mathrm{d}}$ models for all-sky and observed data in wet season.

TABLE 10: CNR1 sites and CG3M sensor characteristics [15].

\begin{tabular}{|c|c|c|c|c|c|c|}
\hline CNR1 station & Location & Lat/long & Primary land use & $\begin{array}{l}\text { Land use within } 1 \mathrm{Km} \\
\text { radius }\end{array}$ & $\begin{array}{c}\text { Elevation of } \\
\text { CG3 sensor } \\
\text { above land }(\mathrm{m})\end{array}$ & $\begin{array}{l}\text { Temporal } \\
\text { resolution } \\
(\mathrm{min})\end{array}$ \\
\hline Deland STP & $\begin{array}{c}\text { Wastewater treatment } \\
\text { plant, Deland, Volusia } \\
\text { Country }\end{array}$ & $29.01 /-81.30$ & $\begin{array}{c}\text { Residential density, } \\
\text { population }=1298 \\
\text { people } / \mathrm{mi}^{2}\end{array}$ & $\begin{array}{l}95 \% \text { urban and } 5 \% \\
\text { mixed Forest }\end{array}$ & 2 & 30 \\
\hline Lindsey Citrus & $\begin{array}{c}\text { Citrus Grove, Indian } \\
\text { River Country }\end{array}$ & $27.58 /-80.60$ & Citrus & $100 \%$ agriculture & 6 & 30 \\
\hline Orange Creek & $\begin{array}{l}\text { District Land, Alachua } \\
\text { Country }\end{array}$ & $29.48 /-82.07$ & Rangeland (bahia grass) & $\begin{array}{c}50 \% \text { rangeland and } \\
50 \% \text { mixed forest }\end{array}$ & 2 & 30 \\
\hline $\begin{array}{l}\text { Ocklawaha } \\
\text { Prairie }\end{array}$ & $\begin{array}{c}\text { District land, Marion } \\
\text { Country }\end{array}$ & $29.10 /-81.91$ & $\begin{array}{c}\text { Wetland (cattail, } \\
\text { Saw-grass, and other } \\
\text { aquatic vegetation) }\end{array}$ & $\begin{array}{c}60 \% \text { wetland, } 20 \% \\
\text { rangeland, and } 20 \% \\
\text { mixed forest }\end{array}$ & 2 & 30 \\
\hline
\end{tabular}

TABLE 11: NOAA stations [15].

\begin{tabular}{lcc}
\hline NOAA station & $\begin{array}{c}\text { Latitude distance to } \\
\text { CNR1 station }(\mathrm{Km})\end{array}$ & $\begin{array}{c}\text { Elevation } \\
(\mathrm{m})\end{array}$ \\
\hline Orlando Sanford Airport & 25.2 & 15 \\
Vero Beach Municipal & 7.8 & 6 \\
Gainesville Regional Airport & 27 & 45.5 \\
Leesburg Municipal Airport & 31.4 & 23.5 \\
\hline
\end{tabular}

effort improved the model with $R^{2}$ values ranging from 0.32 to 0.68 . However, more work is required to further improve the wet season models for the land use areas investigated.

\section{Appendix}

CNR1 sites and CG3M sensor characteristics are shown in Table 10.
The detailed information of NOAA stations was shown in Table 11.

\section{Conflict of Interests}

The authors declare that there is no conflict of interests regarding the publication of this paper.

\section{References}

[1] T. M. Crawford and C. E. Duchon, "An improved parameterization for estimating effective atmospheric emissivity for use in calculating daytime downwelling longwave radiation," Journal of Applied Meteorology, vol. 38, no. 4, pp. 474-480, 1999.

[2] Intergovernmental Panel on Climate Change [IPCC], "Intergovernmental Panel on Climate Change [IPCC]," in Climate Change 2001: The Scientific Basis, J. T. Houghton, Y. Ding, D. J. Griggs et al., Eds., Cambridge University Press, New York, NY, USA, 2001. 
[3] S. Niemela, P. Raisanen, and H. Savijarvi, "Comparison of surface radiative flux parameterizations, part I: long-wave radiation," Atmospheric Research, vol. 58, pp. 1-18, 2001.

[4] N. S. Kruk, Í. F. Vendrame, H. R. da Rocha, S. C. Chou, and O. Cabral, "Downward longwave radiation estimates for clear and all-sky conditions in the Sertãozinho region of São Paulo, Brazil," Theoretical and Applied Climatology, vol. 99, no. 1-2, pp. 115-123, 2010.

[5] A. Angstrom, "A study of the radiation of the atmosphere," Smithsonian Miscellaneous Collecitons, vol. 65, no. 3, pp. 1-159, 1918.

[6] S. B. Idso and R. D. Jackson, "Thermal radiation from the atmosphere," Journal of Geophysical Research, vol. 74, no. 23, pp. 5397-5403, 1969.

[7] G. A. Maykut and P. E. Church, "Radiation climate of Barrow, Alaska, 1962-1966," Journal of Applied Meteorology, vol. 12, no. 4, pp. 620-628, 1973.

[8] J. D. Jacobs, "Radiation climate of Broughton Island," in Energy Budget Studies in Relation to Fast-Ice Breakup Processes in Davis Strait, R. G. Barry and J. D. Jacobs, Eds., pp. 105-120, Inst. of Arctic and Alp. Res. Occas, University of Colorado, Boulder, Colo, USA, Paper no. 26, 1978.

[9] A. D. Culf and J. H. C. Gash, "Longwave radiation from clear skies in Niger: a comparison of observations with simple formulas," Journal of Applied Meteorology, vol. 32, no. 3, pp. 539547, 1993.

[10] M. Aubinet, "Longwave sky radiation parametrizations," Solar Energy, vol. 53, no. 2, pp. 147-154, 1994.

[11] A. C. Dilley and D. M. O’Brien, "Estimating downward clear sky long-wave irradiance at the surface from screen temperature and precipitable water," Quarterly Journal of the Royal Meteorological Society, vol. 124, no. 549, pp. 1391-1401, 1998.

[12] H. F. Duarte, N. L. Dias, and S. R. Maggiotto, "Assessing daytime downward longwave radiation estimates for clear and cloudy skies in Southern Brazil," Agricultural and Forest Meteorology, vol. 139, no. 3-4, pp. 171-181, 2006.

[13] J. Bilbao and A. H. de Miguel, "Estimation of daylight downward longwave atmospheric irradiance under clear-sky and allsky conditions," Journal of Applied Meteorology and Climatology, vol. 46, no. 6, pp. 878-889, 2007.

[14] J. P. Lhomme, J. J. Vacher, and A. Rocheteau, "Estimating downward long-wave radiation on the Andean Altiplano," Agricultural and Forest Meteorology, vol. 145, no. 3-4, pp. 139148, 2007.

[15] M. Rizou and F. Nnadi, "Land use feedback on clear sky downward longwave radiation: a land use adapted model," International Journal of Climatology, vol. 27, no. 11, pp. 14791496, 2007.

[16] V. H. Dale, "The relationship between land-use change and climate change," Ecological Applications, vol. 7, no. 3, pp. 753769, 1997.

[17] A. Kessler, Heat Balance Climatology, World Survey of Climatology, vol. 1A, Elsevier, Amsterdam, The Netherlands, 1985.

[18] A. Kessler and L. Jaeger, "Long-term changes in net radiation and its components above a pine forest and a grass surface in Germany," International Journal of Climatology, vol. 19, pp. 211226, 1999.
[19] S. Barr and D. L. Sisterson, "Locale Analysis Report for the Southern Great Plains," ARM-00-001, Atmospheric Radiation Measurement Program, U.S. Department of Energy, 2000, https://www.arm.gov/publications/site_reports/sgp/arm-00.pdf.

[20] M. Sugita and W. Brutsaert, "Cloud effect in the estimation of instantaneous downward longwave radiation," Water Resources Research, vol. 29, no. 3, pp. 599-605, 1993.

[21] T. Konzelmann, R. S. W. van de Wal, W. Greuell, R. Bintanja, E. A. C. Henneken, and A. Abe-Ouchi, "Parameterization of global and longwave incoming radiation for the Greenland Ice Sheet," Global and Planetary Change, vol. 9, no. 1-2, pp. 143-164, 1994.

[22] C. Elachi, Introduction to the Physics and Techniques of Remote Sensing, John Wiley \& Sons, New York, NY, USA, 1987.

[23] ASOS Program, "ASOS User's Guide," 1998, http://www.nws .noaa.gov/asos/pdfs/aum-toc.pdf.

[24] Z. Kipp, CNR1 Net Radiometer Instruction Manual, Kipp \& Zonen, Delft, The Netherlands, 2000.

[25] W. J. Shuttleworth, “Chapter 4: evaporation,” in Handbook of Hydrology, D. R. Maidment, Ed., McGraw-Hill, New York, NY, USA, 1993.

[26] T. R. Oke, Boundary Layer Climates, Methuen and Co., New York, NY, USA, 2nd edition, 1987.

[27] M. Sieghardt, E. Mursch-Radlgruber, E. Paoletti et al., "The abiotic urban environment: impact of urban growing conditions on urban vegetation," in Urban Forests and Trees, pp. 281-323, Springer, Berlin, Germany, 2005. 

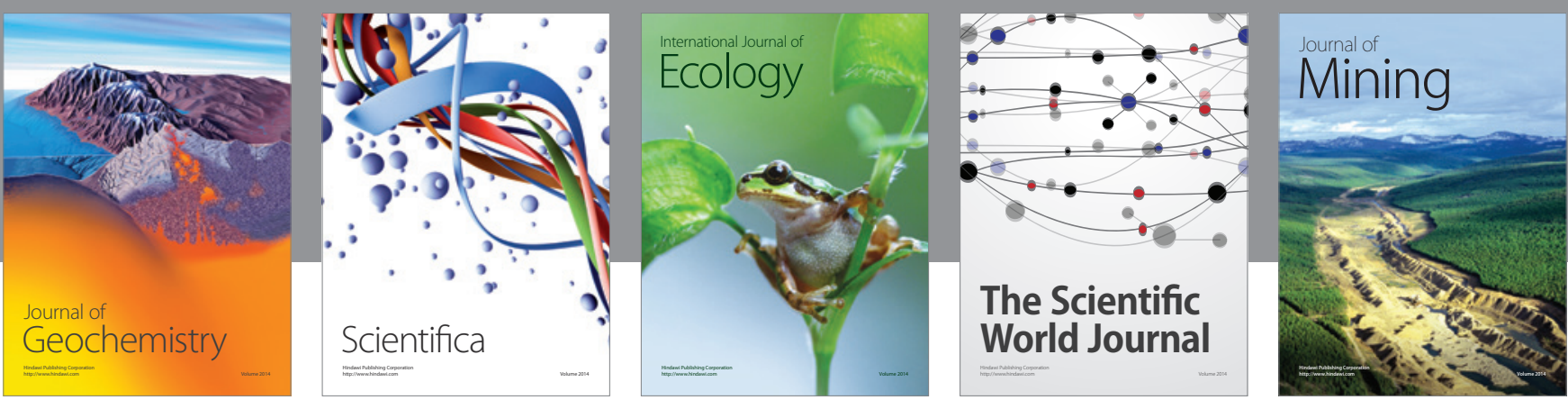

The Scientific World Journal
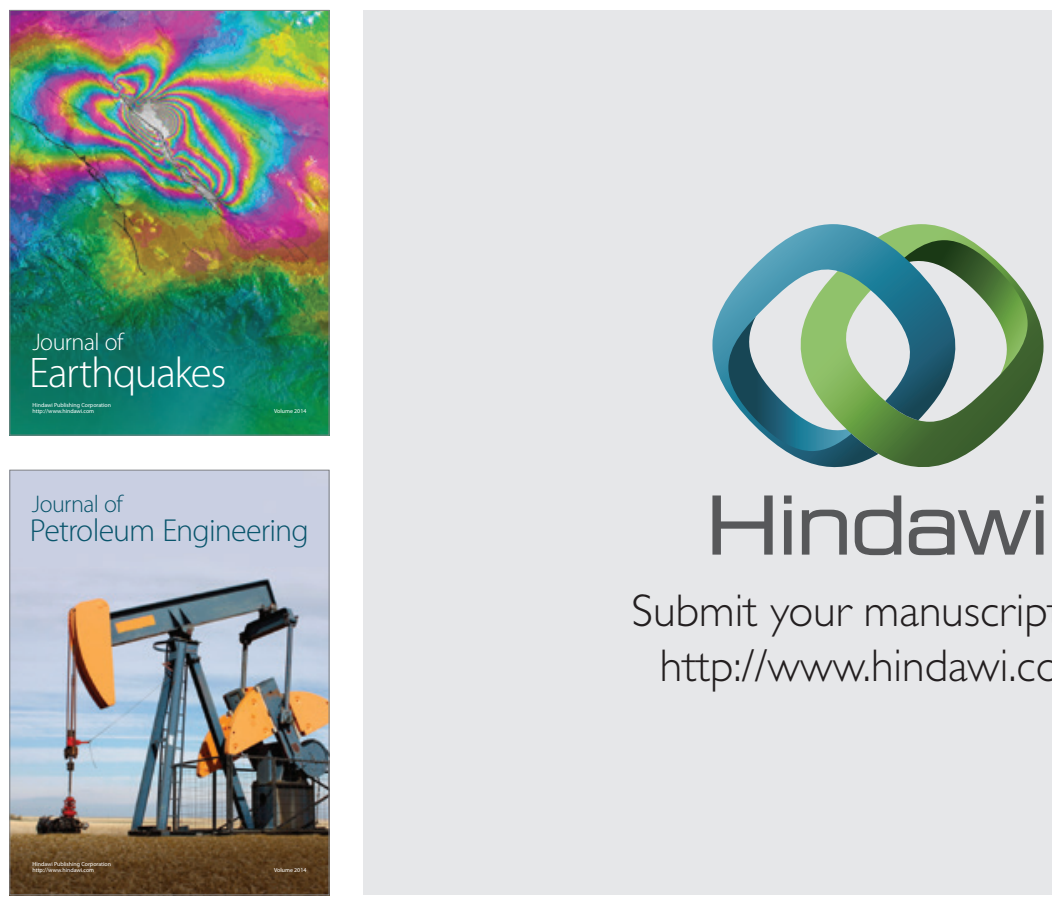

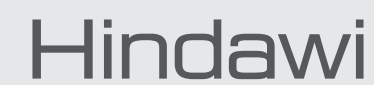

Submit your manuscripts at

http://www.hindawi.com
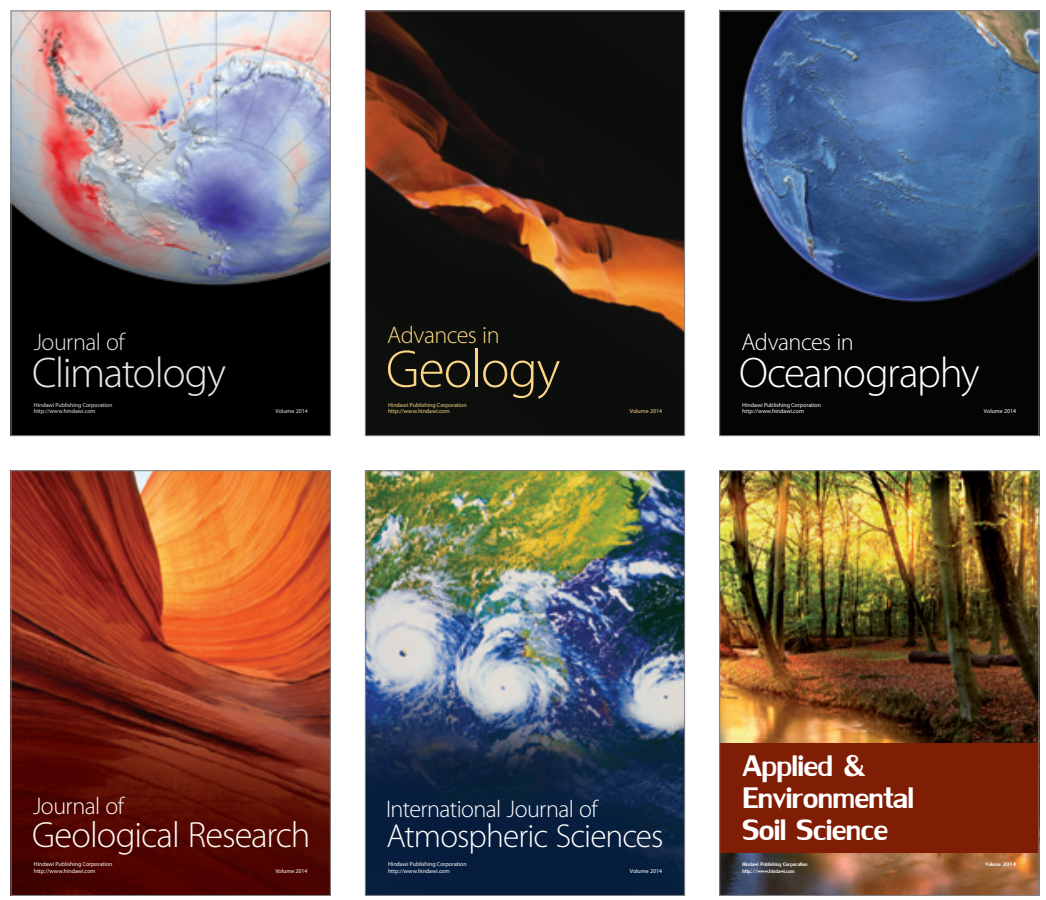
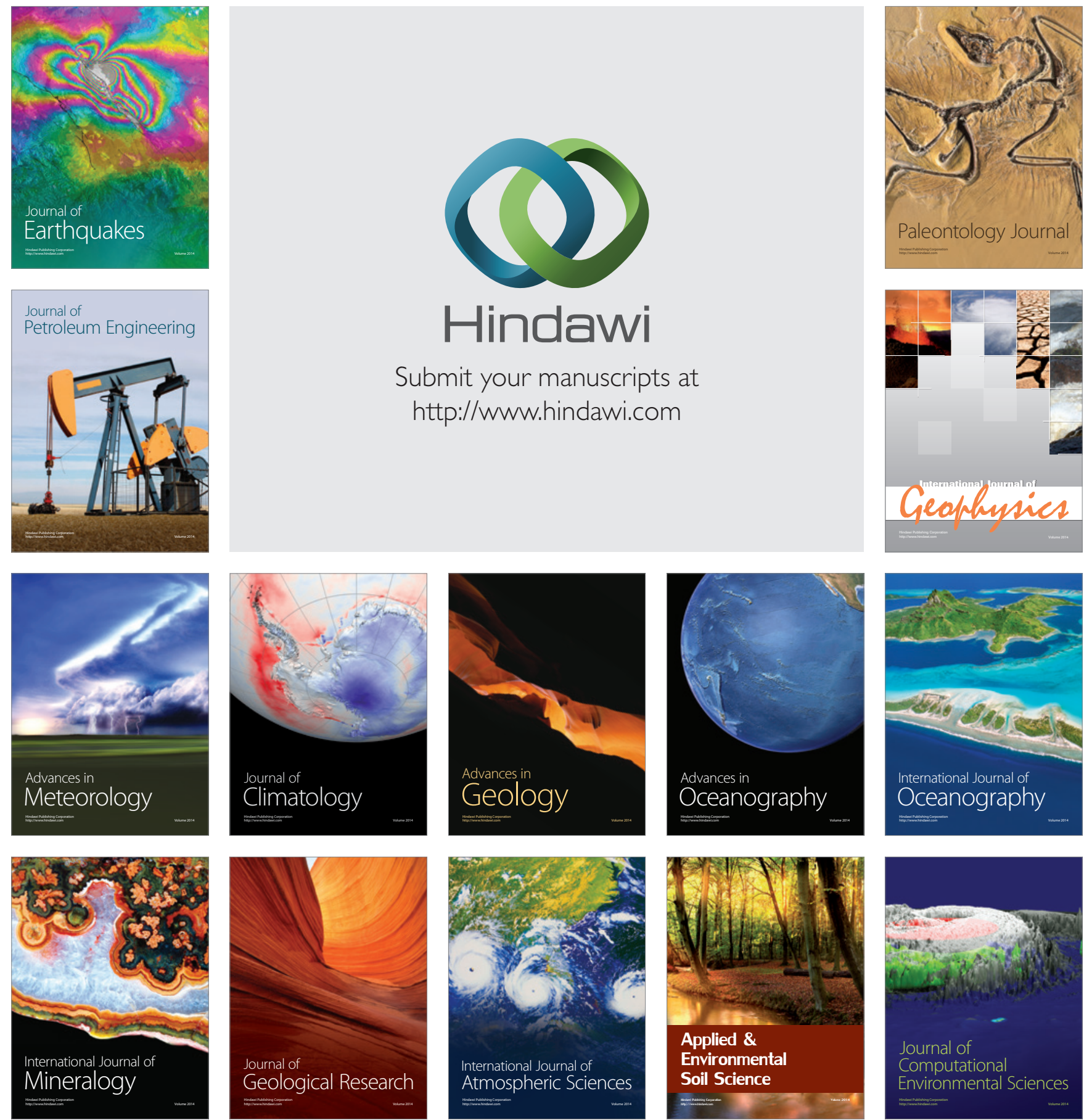